\title{
Editorial
}

\section{RETHINKING SOLIDARITY IN THE EU, FROM FACT TO SOCIAL CONTRACT}

At the time of writing of this editorial, in the high summer of 2011, the 'market forces' are meeting up for an attack on the first major member of the Eurozone, Italy. It begins, as has now become familiar, with a rise in the rate of interest that a country has to pay for money to service its sovereign debt. Above a critical percentage, around seven in this case, the servicing of its debt, compounded with the loss of tax income due to a slackening economy, will send the country into the downward spiral of ever-increasing debt. The perspective of a possible default in turn will send the interest rate further upward, pushing the country into a more certain default, and so on. It is a self-fulfilling perspective.

In the process the attackers, the market forces, are becoming both enervated and invigorated not only by the increasing risk they take in lending to Italy but also by the profit certain of its agents may reap from Italy's ultimate default.

The way out of this spiral may be for the other Euro members to protect Italy from the market by lending money at a lower rate. To the extent that Italy will not be able to jump the vicious circle and will ultimately default nevertheless, the solid members of the Eurozone incur a risk of losing part of the money lent. The onslaught is a test of the Eurozone and the Union's solidarity. Solidarity is now the bottom on which the crisis is played out. How solid is this bottom? Is it relevant at all? In Paris EU Commissioner Barnier, in a criticism of the credit rating agencies, was quoted as saying: 'The objective is not to break the thermometer... but one can't just not take into account the fact that these member states are members of an EU, they benefit from the solidarity of its members....'

In the style of these editorials, let us convert the issue of solidarity from a political problem into the currency of scholarly questions. In terms of scholarship, the questions raised are about the nature and quality, and even about the evolution of solidarity in the context of the EU.

There is no abundance of studies on the subject, to say the least, while obviously it should be a central concern of constitutional thought, especially in these

${ }^{1}$ Financial Times, July 12, 2011.

European Constitutional Law Review, 7: 169-172, 2011

(C) $2011 \mathrm{~T} \cdot M \cdot C \cdot$ ASSER PRESS and Contributors

doi:10.1017/S1574019611200014 
times. What is this quality that binds very different members of a society together and, in turn, that binds very different societies into a solid whole? How can it be understood, be analysed, be seen to evolve? What are its legal and wider, constitutional, expressions? A good discussion may even help better to understand the test to which the Union is currently being put.

The purpose of this editorial is not, of course, to conduct the discussion itself, but to inspire it wherever the opportunity or the drive appears.

\section{Solidarity of fact and of feeling: inarticulate and opposed}

In Robert Schuman's famous words, Europe is not built at once nor from a blueprint, but on the basis of day-to-day achievements, creating first a solidarity of fact (l'Europe ne se fait pas d'un coup ni dans une construction d'ensemble, mais par des réalisations concrètes créant d'abord une solidarité de fait). This actual solidarity of interdependence is, one could say, the basis. Interestingly, in the old distinction of Emile Durkheim this solidarity of interdependence was already seen as the advanced opposite of the 'mechanical' solidarity on which traditional societies are built.

But for us moderns, even the solidarity of actual interdependence is only a beginning. Robert Schuman knew that it would not ultimately suffice. To simplify things one may say that modern national societies, apart from such solidarity of fact or interdependence, demonstrate a cultivated solidarity of feeling between its members, something which among Europeans obviously is still lacking. This explains the reversion to nationalism, and to the solidarity of feeling, in the heat of the debt crisis.

European politicians are very much aware of the existing interdependence combined with the lack of solidarity of feeling. The decision of the British government to support the Irish bail-out financially in November 2010, which was followed by a refusal to support Portugal, ${ }^{2}$ is but one expression of this. The high exposure of British banks in Ireland led to the first decision. The lack of solidarity of feeling to the second.

These forms of solidarity, of fact and of feeling, are at the opposite ends of the spectrum of solidarity. They are both primitive and inarticulate. This is how now they are being pitted against each other.

\section{Solidarity, social}

Between these extremes, across the spectrum, however, are appearing other forms of solidarity, explicit, articulate and better intelligible. The most obvious ones are those that even find legal expression. In the original Treaties the word solidarity

${ }^{2}$ Financial Times, April 9, 2011. 
only occurred as an echo from the Schuman declaration, in the Coal and Steel Treaty's preamble, even if this 'real solidarity' (in the poor English translation of 'solidarité de fait') formed its foundation. In the current Treaty versions, by contrast, solidarity abounds. The Charter of Fundamental Rights lists solidarity among its foundations and spends a whole Title IV on the subject. The EU Treaty in Article 2 lists solidarity not as a foundational value (among respect for human dignity, freedom, democracy, equality etc.) but as one of its prevailing characteristics. This version of solidarity may be called 'social solidarity', a classic of the welfare state. It is also to be found in an increasing number of Union policy documents. ${ }^{3}$ Article 3 introduces solidarity among generations, among Member States and among peoples.

\section{Solidarity, legal and illegal}

The most vital form of solidarity to be found in the Treaties and in legal and constitutional evolution, no doubt is that between the member states. The Lisbon Treaty introduced a solidarity clause between the states, against terrorism and disasters (Article 222(1) TFEU), and financial and energy solidarity in case of natural disasters and exceptional events (Article 122). Paradoxically but maybe not surprisingly, solidarity between member states becomes more important and interesting as it is being less nominally expressed. The Lisbon Treaty introduced solidarity in the form of mutual assistance in case of armed attack in Article 42(7) TEU, an innovation even compared to the Constitutional Treaty, without mentioning the word solidarity itself.

And so we come to the field where solidarity not only is absent in name, but is even prohibited in law, the notorious Article 125 TFEU:

The Union shall not be liable for or assume the commitments of central governments ... of any Member State ... A Member State shall not be liable for or assume the commitments of central governments ... of another Member State.

This legal prohibition has attracted what is no doubt the most telling case of evolution in the field of EU law and constitutionalism. It has not prevented the development of explicit fiscal solidarity among the Eurozone member states, even involving non-Euro states, running squarely against the rule book. On February 11, 2010, the European Council first expressed that the Union would come to the rescue of Greece, if need be (it was then added that no request for aid had yet been made). In April of that year, the actual rescue operation started. The next month, on May 10, in the early morning just before the oriental stock markets would

\footnotetext{
${ }^{3}$ See J. Ottmann, 'The Concept of Solidarity in National and European Law: The Welfare State and the European Social Model', 2 www.icl-journal.com (1/2008), p. 36-48.
} 
open, the Member States initiated a bailout mechanism that was eventually used for Ireland and Portugal.

On 15 December 2010 German Chancellor Angela Merkel in the Bundestag stated the principle of European fiscal solidarity most unequivocally and most tellingly by going straight against Article 125 TFEU. In her Governmental declaration announcing the need of a new Treaty between the Eurozone Countries, she said: 'No one will be left alone, no one will be left to fall' ('Niemand wird allein gelassen, niemand wird fallengelassen').

Merkel's dramatic pronouncements and the events following it of course have not settled the matter of fiscal solidarity in the Union (nor have they settled, for that matter, the issue of the legality of the German participation to the bail-out, on which a pronouncement of the Bundesverfassungsgericht is in store). They have tabled it for the Union's immediate and most urgent agenda. Solidarity is not philanthropy. Even in a fully-fledged social and political community, solidarity is part of a deal.

In the Chancellor's words: 'Solidarity and improvement of competitiveness and before all the economy are two sides of a medal. We may never forget one of the two sides, as Europe in that case would take the wrong path. 'To take responsibility' is that not only we should take responsibility - as we have for the rest demonstrated this year - it means that every single one should take responsibility.'

Solidarity in this explicit form not of one-sided transfers from the well-off to the needy but in the form of mutual responsibility - and responsibility is explicit, articulate and creative, is at the heart of the social contract. Therefore it should be a solid chapter of constitutional thought.

WTE/DN 